\title{
Mechanisms to Improve Citizen Participation in Government and its Administration
}

\section{J Fourie}

\section{School for Public Administration and Management, University of Pretoria}

\section{ABSTRACT}

Citizen participation on any level of government is timeless. The dynamics and the relationships of citizen participation on all levels are unique, due to the fact that many problems and solutions have their roots in the activities of local government and its administration. Furthermore the extension of democracy to all spheres of society and to all tiers of the administrative hierarchy, have been a central theme of the democratisation process in South Africa. The notion of "bringing the government to the people" is important, not only in strengthening civil society, but also in mobilising the population to implement the programmes of reconstruction and development necessary to transform the civil society.

JEL H 11

Citizen participation on any level of government is timeless. The dynamics and the relationship of citizen participation on all levels of government are unique due to the fact that many problems and solutions have their roots in public administration activities. Public administration plays a vital role in educating and mobilising the public with regard to sustainable development.

Furthermore, the extension of democracy to all spheres of society and all tiers of the administrative hierarchy has been a central theme of the democratisation process in South Africa. The notion of "bringing the government to the people" is important, not only in strengthening civil society, but also in mobilising the population to implement the programmes of reconstruction and development necessary to transform the civil society.

It should be pointed out that the history of the democratisation process in South Africa has been a long and painful one. A feature of the apartheid era was systematic emasculation of government in the ongoing efforts to implement apartheid policy. The latter brought about, for example, township riots and 
campaigns of non-payment, the rent boycotts and non-participation by the citizens. The culture of non-payment, so effective in the struggle against apartheid continues to persist in the new dispensation too. Payment, for local government services is however an essential prerequisite in the improvement of service provision. The government now seeks to break up this non-payment logjam by getting the citizen involved in government and its affairs. It should be born in mind that government, especially local government, is the main delivery agent for improvements in housing, health care and infrastructural development (such as electrification and water reticulation). In order to succeed it is therefore important that the citizen should become involved in government and its administration.

As a point of departure, this paper gives a brief outline of the role and purpose of a government, that is, capacity to act, deliberation and openness. With role and purpose in mind, attention is then devoted to the problems and pitfalls of citizen participation in government administration. Thereafter follows a discussion of mechanisms to improve citizen participation in government administration.

\section{EXPOSURE TO THE ROLE AND PURPOSE OF A GOVERNMENT}

Citizen participation needs to be promoted if there is to be true democracy. Democracy rests on the understanding between the citizens and government and its administration. The activities of the authorities should be observed and the individual should be able to participate in government in a constructive manner; if participation is neglected abuse of power may easily take place.

Greatest possible participation in public policy and decision-making requires acceptance of the ethical principle that each citizen of a country has the democratic right to participate in decision-making in all those areas that have a direct influence on that individuals life. This principle of democracy requires that all inhabitants should be involved in one way or the other in decisions on government affairs. The achievement of objectives rests upon the ability of the public administration to have the capacity to act, deliberation and openness. This is discussed below.

\subsection{Capacity to act}

A distinction between the act of controlling government and the act of governing should be made where representative democracy provides the mechanism of control while the bureaucracy, with its professional expertise, is central in the 
task of governing. It is important that representative politicians must not take it on themselves the task of administration or drafting detailed legislation. Democracy and skilled government complement each other and cannot be attained separately. To achieve a balance between these two functions is one of the most difficult and complicated tasks of government.

In emphasising this, it is important to note that a system of good governance requires both the mechanisms of control and for effective action. Openness and deliberation are to be valued, but they lose their lustre in a system that lacks the capacity to act with effective action (Dubnick \& Romzek, 1991: 196 8). Good govemance requires the capacity to act, and therefore bureaucracy and professional expertise are also central to good governance. The management context may vary and a particular organisational form may change, but a large part of the daily work of government is going to be undertaken by full-time professionals, administrators and other employees. From the point of view of the citizen, there are many attractions in letting such people get on with their complex variety of tasks. Many "customers" will be satisfied but appropriate mechanisms are necessary to allow those that are dissatisfied to make themselves heard (Hirschman, 1970: 75).

A good system of governance may well be one in which many people do not exercise opinion, because they are satisfied with the services they receive from the government and its administration. Furthermore people in a Third-World situation are often reluctant to take the initiative, partly because they are not sure of themselves and partly because they are not used to it. They are used to the fact that some authority or organisation takes the initiative and, in most cases, they are quite willing to follow passively (Swanepoel, 1992: 3-4).

It should be noted that the capacity to act concerns more than meeting service delivery objectives, important as they are. In such major issues as unemployment, lack of suitable housing, poverty and crime, a capacity to act is required, which goes beyond the traditional role of state bureaucracy. What is needed is the blending of the resources of government with those of nongovemmental actors. The capacity to provide an integrated approach to social and economic issues rests on partners that are trying to bring together long-term relationships rather than secure for themselves access to immediate spoils.

\subsection{Deliberation}

People are recognised as having the right and the opportunity to take part in public life. Many of their interventions may be specific to the consumption of a particular service. Those interventions should be expected to be short-term, of low cost to the individual and elicit rapid response from the service organisation 
in question. They are likely to deal with matters that are of direct material interest to the person concerned. This does not mean that the outcome will always lead to citizen satisfaction, resource and policy constraints may intervene, but the process should be straightforward and make relatively low demands on time and effort. A citizen orientation of this nature is now justifiably regarded as a commonplace virtue in public service organisations although, of course, the practical situation will always have room for improvement.

The concern with deliberation is a prominent theme in government and democracy (Barber, 1984: 16). Judgements in this content require the sharing of experiences and the give-and-take of collective deliberation. Political institutions should be designed to enable citizens to relate to each other as deliberators or input providers and not as bargainers engaged in exchange (Kymlicka, 1990: 220).

Deliberation should be central to the decision-making of political leaders (Dye, 1984: 19). Rules of procedure, pro rata membership and openness to the public are then part of the process of decision making. Deliberative committees, on the other hand, are considered to be more informal opportunities for policy-making in which politicians can review options in confidence before presenting their final choice of public decisions. In practice, there are an array of working parties and panels for policy deliberation and formulation, alongside the formal decision-making committees. The question may be asked, why is it appropriate for such panels to operate in confidence? An element of reflection behind closed doors is plainly in essential in politics, but the spirit of deliberation being championed in this context argues for a more public process of debate, review and questioning.

What may also have to be considered, is whether different institutional forms of political organisation would create a greater capacity for civic leadership (Dubnick \& Romzek, 1991: 160). Civic leadership does, however, require a commitment to deliberate issues in order to counteract the tendency towards the creation of regime of public and private actors who fulfil their own agendas and serve their self-interest with little regard for the wider concerns of the community (Elkin, 1987: 173).

The spirit of deliberation drawn from communitarian ideas requires that some consideration should be given to involving the broad spectrum of the public in a deliberative setting. Public meetings, forums for the young or the elderly and neighbourhood assemblies could provide appropriate instruments. Each of these instruments has a number of drawbacks in respect of the number and range of responses that they are likely to elicit from citizens. 


\subsection{Openness}

Many people prefer to spend their time on non-political activities or they face social and economic constraints that limit their time for political activity. Openness has many echoes in a long tradition of liberal argument which in its many guises, shares the belief that we promote people's interests by letting them choose for themselves what kind of life they wish to lead (Kymlicka, 1990: 199).

The various instruments of democracy have been subject to critical assessment with regard to their strengths and weaknesses. The main thrust is to create a sovereign democratic state, a diversity of power centres and a world marked by openness, controversy and plurality (Held, 1987: 274). In arguing for open governance, it is possible to draw inspiration from the liberal advocacy of democracy and at the same time recognise the need to meet some of the challenges and difficulties. Party competition for elected offices on a first-pastthe-post basis does not represent the limits of democratic practice. The challenge is to extend citizen control in a way, which does not make excessive demands on their time and provides access to social interests (Ismail, et al., and 1997: 26).

As the world moves into the twenty-first century, it is necessary to progress beyond the watered-down practice of a representative democracy that dominates the system of govemance. The scale, complexity and diversity of the system require one to delve much deeper into a variety of democratic forms and options. An open system of governance would provide scope for each of the three procedures of democratic decision-making: election of representatives, direct voting on issues and participation in meetings. Representative democracy has many attractions and there are many options for enhancing its effectiveness (Gildenhuys, 1997: 32).

Opportunities for voting and other forms of direct participation (such as phonein lines, electronic networks, video interfaces, etc.) could also be introduced. Direct voting could take the form of either referenda or citizen-initiated ballots. It is important to note that here are a number of issues to be considered in the case of binding citizen ballots: the role of pressure groups, stakeholders that are funding publicity, the impact on minority interests and, the oversimplification of complex issues (Caves, 1992). A form of democratic procedure is the involvement of sections of the public in face-to-face meetings. Such procedures are attractive, due to the fact that they present opportunities for deep and intensive involvement. This could encourage participants to move away from a narrow concem with competitive self-interest towards a broader promotion of consensual areas of common concern. Such meetings do, however, have their drawbacks. Some individuals are more willing to participate in them than others. 
It should also be noted that meetings could create a sense of false consensus, masking substantial differences in minority interests and opinions. For these reasons, it is prudent to use face-to-face meetings with circumspection, to restrict their use to debate less divisive issues or to confine their role to consultation rather than taking final decisions. The concerns about face-to-face meetings can however be overcome to some degree and should not be used as grounds to dismiss the contribution made by them to the openness of governance. There is a range of options that could be applied in practice, including the following (Ismail et al., 1997: 110-14):

- public meetings organised to encourage debate on and discussion of a particular issue;

- neighbourhood forums;

- co-option of representatives onto governing bodies;

- user panels;

- public question-and-answer meetings.

Citizens may decide, on reasonable grounds, not to avail themselves of the opportunity to participate, believing that their interests are already well served or not being threatened. The value of openness does not depend on or assume large-scale and continuous direct participation. It rather depends on the richness of the prevailing democratic principles and available options for extending participation. These options should operate without making excessive demands on time and in a way that enhances broad social representativeness.

\section{PROBLEMS AND PITFALLS OF CITIZEN PARTICIPATION IN GOVERNMENT}

In order to evaluate citizen participation in government and its influence on the administrative function, it is important to consider the problems and pitfalls involved. It should be born in mind that South Africa is a young democracy and that the legacy of the past also leads to these problems. The following are some of the issues to be noted:

\subsection{Literacy levels of the citizens}

Education plays an important role in citizen participation and it is according to Anderson (1984: 100) one of the most important means of fostering citizen participation. With this in mind, the education level in especially the rural areas is low due to the fact that many rural schools are poorly endowed with buildings, equipment and books, and without electricity and running water. This brings about high dropout and repetition rates, and long distances to travel to 
school means that many children do not attend school. Furthermore, especially in rural areas, opportunities for secondary and adult education are scarce, and adult illiteracy is therefore much higher in rural than urban areas (Reconstruction and Development Programme, 1995: 23).

These factors mean that potential leaders are not equipped with basic knowledge and skills. This creates a gap where citizens will not be able to understand for example, the political process, policy and decision-making issues, as well as their role in accepting responsibility for their part in the administration of the country.

Lastly, illiteracy causes an inferiority complex. People are afraid to take part, thinking that they cannot make any worthwhile contribution. They believe that innovations must come from educated people of from the privileged, while citizen participation is specifically intended involve ordinary people. Illiteracy also hampers organisational aspects of the administration such as keeping minutes, doing surveys and bookkeeping.

\subsection{Logistical problems, that is, transport problems and telecom- munications}

In expecting citizens to participate in various forums and meetings, it is important that they should in fact be present there, but in developing countries this is a problem due to logistical difficulties especially for people living in remote areas. For example the backlog in the roads network in the rural areas of South Africa is between 30 per cent and 50 per cent (Rural Development Strategy, 1995).

Furthermore, the lack of adequate public transport has resulted in struggles for monopoly of taxi ranks and routes, leading to what are now called "taxi wars". People who have vested interests in taxis and those who wish to destabilise communities through fear, intimidation and violence exacerbate conflict. Such destabilisation could result in the undermining of the democratic process and also prevent citizens from participating in actions the government wants to take to reduce the influence of "taxi lords" (Taylor, 1995: 173).

Another example of logistical problems is represented by telecommunications, were there are 9.5 telephone lines per 100 people overall in South Africa. It is estimated that there are 60 lines per 100 people in White areas, whereas there is only one line per 100 people in Black areas (SAIRR, 1997: 778).

The aforementioned is only an indication of some of the problems in citizen participation on account of the logistical problems of getting the citizens to a 
meeting or a forum, or to do telephone surveys or to inform the citizen about new developments.

\subsection{Inexperienced officials to deal with the needs and demands of the citizens}

Most governments train their staff to be professionals. It is required of them in such professional fields as agriculture, health or civil engineering to be in possession of a diploma or degree from an accredited institution. In-service training, aimed at updating the employees' professional knowledge, will then follow up this formal education. While professional training is very important and necessary, it nonetheless poses a serious problem for citizen participation. Officials are not trained in the basic theories of democratic practice, the practice of development and have not been trained to understand sociological phenomena that influence their work. They also lack psychosocial skills, with the result that they find it very difficult to work with people and to understand people's sentiments and actions (Swanepoel, 1992: 112).

\subsection{Related problems that prevent citizen participation}

The abovementioned issues are only a few examples. The following may also hamper citizen participation in public administration: (Swanepoel, 1992: 112)

Customs and traditions: People are obligated to follow customs and traditions even if they are involve in the administration. The submissiveness to traditional leaders (in South Africa approximately 18 million people are under the rule of traditional leaders) and the inferior position of women are examples of this. This does not mean that customs and traditions are obstacles per se, on the contrary, they can be valuable resources. Customs and traditions are not static; they have the tendency to adapt to suit modern times. However, where people keep them static for some reason, they can indeed become obstacles in the way of citizen participation.

- Dependency: People may become so used to being dependent on the administration and other agencies, that receiving handouts becomes the norm. They are then loath to do anything for themselves and come to expect to be paid for any part of an effort to get them involved in the administration of the government.

- Apathy: Yet another issue that should be noted of in this context, is that of apathy where people have become so used to being poor and suffering all the consequences of poverty, that they have no real wish to participate but only to survive. Unfortunately they truly sustain their poverty and misery by accepting it as fate, and may be fearful to participate in initiatives 
undertaken by the administration because it could lead to even further suffering.

The problems mentioned above cannot be ignored, and citizen participation should be to remove them. Every government agency should take note of them (to ignore them will not make them to go away), address them and must, to a certain extent, also accommodate them. In short, these obstacles are real obstacles citizen participation in public administration, and ignoring them or trying to break them down by brute force will only be detrimental to it.

\section{MECHANISMS TO IMPROVE CITIZEN PARTICIPATION IN GOVERNMENT AND ITS ADMINISTRATION}

There are number of traditional mechanisms to improve citizen participation in government and its administration. These traditional mechanisms include the introduction of user groups, liaison panels, public question-and-answer occasions, forums to improve planning, decision-making and policy implementation (Starling, 1992: 160-61; Ball, 1995: 15-20; Barnes et al., 1996: 9-17). This part of the paper looks beyond the traditional mechanisms whereby the citizen would be actively involved and also accept responsibility. Accepting responsibility means that there should co-operation between public administrators and citizens, so that there can be joint action and joint responsibility (Thornhill \& Hanekom, 1995: 43). This section addresses the process of facilitating citizen involvement, enhancing the education of citizens and specifically stresses the role of mentorship and support, enhancing administrative capacity by equipping officials with the necessary skills to meet the demands of the citizens. Attention is also given to the issue of providing a valuable service close to the citizen, building partnership and trust by following certain strategies and lastly maintaining citizen enthusiasm for participation in the administration of government.

\subsection{Facilitating citizen participation}

In order to facilitate community involvement, a number of options may be followed to enhance citizen participation. Responsibility for implementing a project may lie with a community, a local, provincial or national authority. Wherever it lies, the beneficiary community must be involved in all stages of project identification and development. Once a project has been identified and agreement reached that it should be implemented, the beneficiary community should be made aware of this by using the media as well as passing information through established community organisations. The options below may be 
implemented to promote community participation (Guidelines for enhancing employment opportunities in the delivery of infrastructure projects, 1998).

\subsubsection{Project Steering Committee}

The aim of the PSC will be to look after the interests of the community. The implementation agent is responsible for making arrangements for the establishment of the PSC and for drafting and agreeing with the PSC terms of reference. Representatives of the community should be the dominant force of the PSC and represent the composition of the community with regard to the numbers of women, youth, unemployed people etc. The PSC should include the political representative of the community, representatives of community organisations and local interest groups, for example, an environmental study group.

\subsubsection{Scope of social and development compacts}

Social and development compacts are required to enable agreement to be reached at the level of the local authority, where its structure does not have the capability to co-ordinate development. Where local authorities have established permanent structures to deal with development issues and to co-ordinate all development projects, it will not be necessary to establish a social compact. This structure can however successfully facilitate delivery and assist the beneficiaries in entering into a development compact.

\subsubsection{Appointment of a facilitator}

The appointment of a facilitator should take place as soon as the client organisation (funding institution) is committed to a project. The facilitator must be acceptable to the community and be able to communicate freely with community members. The facilitator should be a member of the community and the necessary training is to be provided. The facilitator should support the local authority and keep it fully informed of his activities.

\subsubsection{Community liaison officer}

The employment of a community liaison officer (CLO) to act as go-between for the work force (project participants), the contractor and the PSC has been found to be of benefit in avoiding potential conflict. The duties and employment conditions of the CLO should be laid down in form of a contract of employment. The CLO must be respected by the community and the method of appointment should be transparent and agreed upon between the client, PCS and contractor. 


\subsection{Improving citizen education}

To enable citizens to participate and communicate intelligibly, frankly, legitimately and in a truthful manner, they should have a basic knowledge of and skills in the citizen participation process (Thornhill \& Hanekom, 1995: 41). But active and knowledgeable citizenship is not something that develops without conscious effort to encourage it. Citizens need certain stimuli to encourage participation in specific programmes and activities. Education is one of the most useful means of deliberate action to equalise divergent approaches, for example, by affluent areas or disadvantaged groups.

It should be bome in mind that the process of education is not a one-sided exercise; it is twofold where the public official has the duty to educate the members of a community in their various roles and responsibilities. On the other hand education also is a task of the leaders in the community, and of community-based and non-governmental organisations.

The stress on educating the citizen should be on the dynamics of political intentions and it is therefore important that target groups be guided in the correct way and in the desired direction with regard to the openness of government and its administration, certain basic principles should be followed. These could include:

- the right of citizens to express their ideas about management and administrative issues;

- a need for the opportunity to exchange ideas; and

- well-deliberated and sensible inputs for decision-making.

In terms of education, support and mentorship, the administration should also play an important role. Mentoring of citizens should not be seen as a one-way street on the part of the administration but as a means of providing experience to the citizen who wants to play an active role in the administration. Mentors should perceive the need to contribute to the growth, development and satisfaction of citizens. They should also be responsible for conveying and upholding the standards, norms and values of the community. The nature of the relationship between the mentor and the citizen should be formalised and allowed to develop over time.

\subsection{Improving administrative capacity by training officials}

Although this may seem a cliché, the role of training in dealing with citizens cannot be ignored. Therefore it should be noted that training means any action necessary to develop applied knowledge, expertise or inclination with the view 
to better qualifying a person for work related to a government body, and it includes supplying guidance to members of government bodies.

Officials will have to be trained on a regular basis to facilitate a behavioural change and sensitise them to the changing needs and aspirations of the citizens. It is also true that officials may feel threatened or insecure about citizen participation in the administration. They may feel that drawing citizens into participation in government affairs will be just another way of rationalising their institutions, which could result in redundancies and early retirements. Training programmes should therefore also be provided to officials to eliminate fear and misunderstanding (Bekker et al., 1995: 85-86).

The selection of the right officials to deal with the community is critical. It may be necessary to review an official's performance regularly and make changes if needed. A trained official should be able to perform the following functions designed to encourage citizen participation:

- Assist the community organisations in carrying out skills and resource audits.

- Communicate on a regular basis with the citizens involved, to determine needs and aspirations.

- Identify possible issues, which could disrupt relationships and trust between the community and the administration as soon as possible.

- Ensure that citizens are informed about their rights and privileges.

\subsection{Providing a valuable service to be close to the citizen}

For a service to be of value to them it must be wanted by the citizens and be of an acceptable quality. Getting closer to the citizen can only do this and although this of importance for all public services it should be borne in mind, that this is the only way to enable public service providers to respond to the changing needs of the citizens (Constitution of the Republic of South Africa, 1996).

Public administration is moving away from the old one-way relationship with the citizens, in which people were simply seen as recipients of services. Therefore, as public administration seeks to form closer relationships, it could utilise a number of ways to be close to the citizen in assessing the value of the service provided (Atkinson \& Boyle, 1996: 22). This may include surveys, focus groups, consumer panels and general discussions. It is important to choose a method that is understandable at the level of education of the citizen. For example, the use of a questionnaire could be suspect due to the possible manipulation, and representation of views is difficult to collect, as people who have a specific concern or designation are far more likely to contribute to 
research than those without. Those who are visible and/or active during meetings are not necessarily those in greatest need (Robinson \& Wolsey, 1996: 67). To avoid the problems mentioned above, the role of the facilitator as explained in 4.1 .3 becomes increasingly important in assessing the real need for service delivery by the administration.

\subsection{Building partnerships and trust with citizens}

One of the strengths of integrated public administration is that it recognises the linkages between development, delivery and democracy. Public administrations require active participation by citizens at four levels:

- As voters, to ensure maximum democratic accountability of the elected political leadership for the policies they are competent to promote.

- As citizens, who express through various stakeholders associations their views before, during and after policy developments, so that policies reflect community preferences as far as possible.

- As consumers or end-users, who expect value for money, affordable services and courteous and efficient service.

- As organised partners, involved in the mobilisation of resources for development.

In building participation and trust with the citizens, either the "top-down" or "bottom-up" approach could be followed. The first-mentioned is a one-way process, dominated by the public administration, whereas the last-mentioned process is a two way process that develops into a genuine dialogue between the administration and the citizen. It should be kept in mind that the reality is complex. With this in mind, a closer look is taken at each of the two processes below:

\subsubsection{The top-down strategy}

In the top-down strategy the public administration remains firmly in control. This means it will (Young, 1996: 26):

- $\quad$ set up a one-way process;

- pass down information to citizens and interest groups about what the administration is doing;

- $\quad$ set the agenda and control it during the participation process;

- choose the policy to be followed and its priorities;

- dominate the participation process itself; and

- manipulate the process of participation to ensure that there is no real scope for change to its position after it has been completed. 
The top-down strategy usually occurs where the administration intends to publicise what it has been doing, and what it plans to do in future. This form of participation helps the administration to legitimise its activities (Swanepoel, 1992: 108-9). It should be kept in mind that although this process is widely criticised for not allowing real input from citizens it could be used as a point of departure where the citizens have no wish to participate. This mechanism should then be used with great care and only if necessary. It may be noted that citizens in a Third-World situation are often reluctant to take the initiative, partly because they are not sure of themselves and partly because they are not used to participation. They are rather used to the fact that some authority or organisation takes the initiative. In most cases, they are quite willing to follow passively. There may be very good reason for this attitude, for example that the opportunity for conflict in a society is much diminished when decisions are made externally.

\subsubsection{The bottom-up strategy}

In contrast the bottom-up strategy may be followed and this approach could then lead to citizen empowerment. In this case the administration will follow a different approach in allowing the citizens to participate in the administration. The administration will then (White Paper on Transforming Public Service Delivery, 1997):

- conceive participation as a genuine two-way dialogue based on the sharing of information and knowledge;

- aim to reach out beyond the groups that are usually involved in participation, to give people a genuine role in shaping the decisions of the administration;

- follow a hands-off approach, listening stance and aim to empower people;

- leave the agenda open, which will then set by the citizens;

- leave the direction of policy and the choice of the priorities open to discussion;

- share power with the participants: the participation process will then became part of day-to-day administration; and

ensure that it has wide scope to change its position once the participation process is over.

Administrations promoting the bottom-up strategy should keep the following basic principles in mind (Young, 1996: 29-30):

- the administration should develop a culture of listening, both at meeting and afterwards in internal discussions; 
- to encourage trust, it is important the administration brings in outsiders as convenors, chairs and facilitators. (Outsiders are normally seen as unbiased);

- administrations should provide support for officials to for example, arrange meetings, distribute the necessary information and take down the minutes. In the process of empowerment it is important that the citizens should also take over some work between the meetings;

- that a blank agenda should always be a starting point where the citizens set out their needs and aspirations; and

- that responsibilities are shared between the administration and the citizens in meeting these needs and aspirations. Co-operative responsibility is then required.

In building trust and partnership between the citizens and the administration, the latter should prevent a hands-on approach and rather adopt a more open-minded attitude than in the past, when citizens were merely seen as the receivers of services.

\subsection{Maintaining citizen enthusiasm to participate}

It is true that when people feel obliged to participate in the administration of government and that it could have a negative influence on those who really want to participate. For those who want to play an active role, it is important to maintain the enthusiasm to participate in government programme, be it planning, policy and decision-making issues or service projects such as roads, health care, housing or environmental issues. The following hints could serve to maintain enthusiasm (Swanepoel, 1992: 9-10):

- That the collective objective is reachable in a short period.

- Programme planning should make provision for regular milestones. Milestones could be use as a measurement tool to encourage the participants to follow the objectives.

- Programme planning should make provision for the unexpected failure and these failures should be communicated to participants who could assist in drawing up of alternative programmes.

- Participants should be given credit for accomplishments on achievements.

\section{CONCLUSION}

The phenomenon of citizen participation has become a major challenge for public administration. Public administrators are forced to take the initiative in identifying and implementing means to accommodate citizens needs and 
aspirations to participate in the processes of public administration, be it decision making or other activities. Public administration in the democratic state starts and ends with the needs and the expectations of the citizens. It is therefore important for citizens to be qualified and willing to make their own inputs for obtaining satisfaction of their justified needs and expectations. Education thus becomes an important condition for citizen participation in effective, deliberation and to be able to act accordingly.

Public administrators have the responsibility to make citizens aware of their role in effective participation through mentorship and support. There is an increasing need for citizens to effectively work along with the government of the day to ensure successful governance. Although traditional mechanisms are not to be neglected, it is important to look beyond these in order to promote the process of citizen participation.

Because the interests of the citizens are at stake, it is self-evident that they should take part in the activities of public institutions in providing the goods and services required for the maintenance and promotion of the general welfare. It is therefore important that citizens to be able to make specific inputs, in other words, they must serve as responsible partners of the government and administration.

Lastly, the most urgent challenge for any government that claims to be democratic, is to build a society motivated by participation. The requirements of democracy are met when the opportunities for citizen participation are present, irrespective of whether the citizen participates or not.

\section{REFERENCES}

1 ANDERSON, C. (1977) Statecraft: An Introduction to Political Choice and Judgement, New York, Wiley.

2 ATKINSON, S. \& BOYLE, J. (1996) "Young People and Local Authorities: What Can We Do to Make Them More Interested - Should We Bother?", Local Government Policy Making, 23(3).

3 BALL, J. (1995) "Community Governance - The Arun Experience", Local Government Policy Making, 22(3) December.

4 BARBER, B. (1984) Strong Democracy: Participatory Politics for a New Age, California, University of California Press.

5 BARNES, M.; HARRISON, S.; MORT, M; SHARLOW, P. \& WISTOW, G. (1996) "Users, Officials and Citizens in Health and Social Care", Local Government Policy Making 22(4), March. 
6 CAVES, S. (1992) Land Use Planning, The Ballot Box Revolution. Newbury, California, Macmillian Publishing Company.

7 DUBNICK, M.J. \& ROMZEK, B.S. (1991) American Public Administration - Politics and the Management of Expectation, New York, Macmillian Publishing Company.

8 DYE, T.R. (1984) Understanding Public Policy, (5 $5^{\text {th }}$ ed.), Englewood Cliffs, Prentice-Hall, Inc.

9 ELKIN, S. (1987) City and Regime in the American Republic, Chicago, University of Chicago Press.

10 HELD, D. (1987) Models of Democracy, Cambridge, Polity.

11 HIRSCHMAN, A. (1970) Exit, Voice and Loyalty: Responses to Decline in Firms, Organizations and States, Cambridge, Polity.

12 ISMAIL, N.; BAYAT, S., \& MEYER, I. (1997) Local Government Management, Halfway House, International Thomson Publishing (Southem Africa)(Pty) Ltd.

13 GILDENHUYS, J.S.H. (1997) Introduction to the Management of Public Finance - A South African Perspective, Pretoria, J.L van Schaik Publishers.

14 KYMLICKA, W. (1990) Contemporary Political Philosophy, Oxford, Clarendon.

15 RECONSTRUCTION AND DEVELOPMENT PROGRAMME, (1994) White Paper, Pretoria, Government Printer.

16 ROBINSON, L. \& WOLSEY, C., (1996) "Considerations in Developing the Public Service Orientation", Local Government Policy Making 23(1) July.

17 STARLING, G. (1993) Managing the Public Sector ( $4^{\text {th }}$ ed.) Belmont, California, Wadsworth Publishing Company.

18 SOUTH AFRICA (REPUBLIC) (1995) Rural Development Strategy of the Government of National Unity, Ministry in the Office of the President. Pretoria, Government Printer.

19 SOUTH AFRICA (REPUBLIC) (1996) The Constitution of the Republic of South Africa, Act No 108 of 1996, Pretoria: Govemment Printer.

20 SOUTH AFRICA (REPUBLIC) (1997) White Paper on Transforming Public Service Delivery, Department of Public Service and Administration. Pretoria, Government Printer.

21 SOUTH AFRICAN INSTITUTE OF RACE RELATIONS (SAIRR) (1997) South African Sunvey 1996-1997, Johannesburg.

22 SWANEPOEL, H. (1992) Community Development - Putting plans into action, Kenwyn, Juta \& Co, Ltd.

23 TAYLOR, V. (1995) Community Empowerment, in Craig, G and Mayo, $M$ (eds.) Social Reconstruction and Community Development in the Transition to Democracy in South Africa, London, Ed Books. 
24 THORNHILL, C. \& HANEKOM, S.X. (1995) The Public Sector Manager, Durban, Butterworths.

25 YOUNG, S. (1996) "Stepping Stones to Empowerment? Participation in the Context of Local Agenda 21", Local Government Policy Making, 22(4), March. 